\title{
Technical Note \\ Easy Removal of Epiphytic Bacteria on Ulva (Ulvophyceae, Chlorophyta) by Vortex with Silica Sands
}

\author{
Xiaojie Liu ${ }^{1,2,3}$, Jin Zhao ${ }^{1,2}$ and Peng Jiang ${ }^{1,2, * \mathbb{C}}$ \\ 1 CAS and Shandong Province Key Laboratory of Experimental Marine Biology, Center for Ocean \\ Mega-Science, Institute of Oceanology, Chinese Academy of Sciences, Qingdao 266071, China; \\ liuxiaojieyx@163.com (X.L.); zhaojin@qdio.ac.cn (J.Z.) \\ 2 Laboratory for Marine Biology and Biotechnology, Qingdao National Laboratory for Marine Science \\ and Technology, Qingdao 266237, China \\ 3 College of Earth Sciences, University of Chinese Academy of Sciences, Beijing 100049, China \\ * Correspondence: jiangpeng@qdio.ac.cn
}

check for updates

Citation: Liu, X.; Zhao, J.; Jiang, P. Easy Removal of Epiphytic Bacteria on Ulva (Ulvophyceae, Chlorophyta) by Vortex with Silica Sands. Microorganisms 2022, 10, 476. https://doi.org/10.3390/ microorganisms10020476

Academic Editors: Simon Dittami, Catherine Leblanc, Suhelen Egan and Aschwin Engelen

Received: 31 December 2021 Accepted: 15 February 2022 Published: 21 February 2022

Publisher's Note: MDPI stays neutral with regard to jurisdictional claims in published maps and institutional affiliations.

Copyright: (c) 2022 by the authors. Licensee MDPI, Basel, Switzerland. This article is an open access article distributed under the terms and conditions of the Creative Commons Attribution (CC BY) license (https:/ / creativecommons.org/licenses/by/ $4.0 /)$.

\begin{abstract}
Macroalgae-associated bacteria play an important role in their algal hosts' biological processes. They are localized on surfaces of the host thalli, as well as between and even within algal cells. To examine the differences in community structures and functions between epi- and endo- bacteria, an effective approach for maximizing epiphyte removal from delicate seaweeds while retaining endophyte fidelity must be developed. In this study, a variety of surface sterilization methods for Ulva prolifera were compared, including mechanical, chemical, and enzymatical treatments. According to the results of scanning electron microscope (SEM) and denaturing gradient gel electrophoresis (DGGE) analysis, almost complete removal of epiphytic bacteria on Ulva was obtained simply by co-vortex of seaweeds with silica sands, causing minimal disturbance to endosymbionts when compared to previous published methods. In addition, the adaptability was also confirmed in additional $U$. prolifera strains and Ulva species with blade-like or narrow tubular thallus shapes. This easy mechanical method would enable the analysis of community composition and host specificity for Ulva-associated epi- and endo-bacteria separately.
\end{abstract}

Keywords: associated bacteria; seaweed; silica sand; surface sterilization; Ulva

\section{Introduction}

Macroalgal-bacterial associations were demonstrated to be widely distributed in marine habitats [1]. Bacterial communities have been shown to play a key role in terms of algal growth [2], nutrition acquisition [3], resistance to biofouling [4], adaptation to environmental stresses [5], spore germination, and colonization of seaweeds [6], and may even act as an indispensable factor in algal morphogenesis process [7-12]. Macroalgae-associated bacteria were found on surfaces of host thalli, as well as between or even within algal cells $[13,14]$. These two groups of bacteria were known as epiphytes and endophytes, respectively. However, the differences in bacterial composition and host specificity between these two groups of bacteria have not been of concern until recently [15-18]. To quantitatively compare this variation using high-throughput sequencing techniques, it was essential to develop an effective method that can remove epiphytic bacteria as much as possible while simultaneously maintaining the fidelity of the endosymbiotic bacteria.

Among reported enzymatic and chemical methods applied to macroalgae, the UNSET buffer (urea and SDS as principal ingredients) and 3M $\mathrm{M}^{\mathrm{TM}}$ Rapid Multi-Enzyme Cleaner (Sydney, NSW, Australia) were designed for selective collection of epiphytic bacteria $[19,20]$. Although both of them were successful in obtaining representative samples for epiphytes, the staining with fluorescent dye 4',6-diamidino-2-phenylindole (DAPI) still showed that some bacteria remained on the outer surface of algae, which made the algal thalli not suitable for the extraction of endophytes [21]. To make the endophytes completely free from 
epiphytic contamination, the bleach-ethanol treatment was employed to obtain epiphytesfree macroalgae $[22,23]$. However, this protocol was too aggressive for delicate algae and would greatly reduce the abundance of endophytes [21]. A more balanced protocol was developed in which the macroalgae were treated with cetyltrimethylammonium bromide (CTAB) and proteinase $\mathrm{K}$ at $60^{\circ} \mathrm{C}$ for $30 \mathrm{~min}$, followed by incubation with Umonium Master (bactericidal cleanser) overnight [21]. However, high-temperature treatment could alter the abundance of endophytes communities to some extent [24] and was likely to significantly affect further transcriptome analysis. Thus, for delicate seaweeds, an effective method to meet the demand to maximize the removal of epiphytes, while causing little disturbance to endophytes, is still missing.

Species of green seaweeds Ulva (Ulvophyceae, Chlorophyta) often have the simple shape of either blade-like or tubular thalli, and they are typical opportunistic seaweeds. Once the environmental conditions are suitable, they can grow rapidly, sometimes causing massive green tides and serious economic losses $[25,26]$. In addition, some morphological variations which may benefit their floating lifestyle, were always observed during the blooming stage [27-29]. It has been hypothesized that the associated bacteria with Ulva spp. may contribute greatly to the blooming of their hosts, possibly by providing assistance on nutrition acquisition $[17,30]$ or inducing floating-adaptive morphology. In this study, we attempted to develop an efficient protocol to maximize the removal of the epiphytic bacteria while maintaining the native endophytic community for the blooming-causative green seaweed U. prolifera O.F. Müller [31,32], facilitating the analysis of community composition and host specificity for Ulva-associated epi- and endo-bacteria separately.

\section{Materials and Methods}

\subsection{Algal Samples}

Two floating $U$. prolifera strains, S1 and S3, were collected from the Qingdao coast during the blooming periods of green tides in 2007 and 2014, respectively, and an attached strain S2 was collected from Lianyungang coast in 2011. Unialgal cultures of S1 and S2 were grown in Von Stosch's Enriched Medium at $20^{\circ} \mathrm{C}$ under a 12:12 h light:dark cycle with a photon flux rate of $60 \mu \mathrm{mol} \mathrm{m}{ }^{-2} \mathrm{~s}^{-1}$. Strain S3 was frozen at $-20^{\circ} \mathrm{C}$ right after sampling. The attached specimens of $U$. linza Linnaeus and $U$. compressa Linnaeus were sampled from the Qingdao coast in 2014 just before the sterilization experiments.

\subsection{Sterilization and SEM Detection}

As shown in Table 1, cultured samples from strain $\mathrm{S} 1$ of $U$. prolifera were subjected to a single or a combination of several mechanical, enzymatic or chemical sterilization protocols. Silica sands (Ruijinte Ltd. Com., Beijing, China) in two grain sizes, 60-125 $\mu \mathrm{m}$ and $125-250 \mu \mathrm{m}$, were obtained by grinding and gradient screening. To evaluate the adaptability of the optimized method for other Ulva spp., we applied it to two other strains of $U$. prolifera, i.e., S2 and S3 (normal and frozen samples respectively) as well as two other species including $U$. linza and $U$. compressa. Each protocol was followed by three times of brief wash and vortex step in sterile seawater. All treatments were repeated in triplicate, and effects on both epiphytes removal and intactness of algal cell wall were assessed using the scanning electron microscope (SEM, S-3400N, Hitachi, Tokyo, Japan), which was a more stringent method than DAPI staining. SEM detection was performed following the protocols described by Callow (1978) [33]. All tissues were fixed by $5 \%$ glutaraldehyde for $12 \mathrm{~h}$, then gradient dehydration was carried out with 30,50,80,90, and 100\% ethanol at room temperature for $15 \mathrm{~min}$. Samples were then dried at a critical point, coated with gold-palladium by direct-current sputtering, and examined under SEM. 
Table 1. Protocols applied for the surface sterilization of Ulva thallus.

\begin{tabular}{|c|c|c|c|}
\hline Type & Group No. & Sterilization Method & Extended Protocol \\
\hline \multirow{2}{*}{ Control } & a & no & fresh S1, control for groups from c to o 4 \\
\hline & $\mathrm{b}$ & no & frozen S1, control for group o5 \\
\hline \multirow{8}{*}{ Enzymatic } & c & lysozyme (AMRESCO, Solon, OH, USA) & $\mathrm{S} 1+2 \mathrm{mg} / \mathrm{mL}$ lysozyme in SSW ${ }^{1}, 37^{\circ} \mathrm{C} \times 1 \mathrm{~h}$ \\
\hline & d & papain & $\mathrm{S} 1+2 \mathrm{mg} / \mathrm{mL}$ papain in SSW, $55^{\circ} \mathrm{C} \times 30 \mathrm{~min}$ \\
\hline & e & snailase & $\mathrm{S} 1+2 \mathrm{mg} / \mathrm{mL}$ snailase in SSW, $37^{\circ} \mathrm{C} \times 1 \mathrm{~h}$ \\
\hline & $\mathrm{f}$ & cellulase & $\mathrm{S} 1+2 \mathrm{mg} / \mathrm{mL}$ cellulase in SSW, $25^{\circ} \mathrm{C} \times 2 \mathrm{~h}$ \\
\hline & $\mathrm{g}$ & lysozyme + papain + snailase & S1 + mixture of lysozyme, papain, and snailase \\
\hline & 0 & & $\begin{array}{l}(2 \mathrm{mg} / \mathrm{mL} \text { each }) \text { in SSW, } 37^{\circ} \mathrm{C} \times 1 \mathrm{~h} \\
\mathrm{~S} 1+\text { EDTA and filter-sterilized rapid multienzyme cleaner }\end{array}$ \\
\hline & $\mathrm{h}$ & rapid multienzyme cleaner & $\begin{array}{c}\left(3 \mathrm{M}, \text { North Ryde, NSW, Australia) in CFASW }{ }^{2} \text {, }\right. \\
\text { room temperature } \times 2 \mathrm{~h}\end{array}$ \\
\hline & $\mathrm{i}$ & proteinase $\mathrm{K}$ & $\mathrm{S} 1+2 \mathrm{mg} / \mathrm{mL}$ proteinase $\mathrm{K}$ in $\mathrm{SSW}, 60^{\circ} \mathrm{C} \times 30 \mathrm{~min}$ \\
\hline \multirow{3}{*}{ Chemical } & j & ethanol & $\mathrm{S} 1+75 \%$ ethanol, room temperature $\times 5 \mathrm{~min}$ \\
\hline & $\mathrm{k}$ & bleach & $\mathrm{S} 1+3 \%$ sodium hypochlorite, room temperature $\times 30 \mathrm{~s}$ \\
\hline & 1 & UNSET buffer & $\mathrm{S} 1+1 \mathrm{~mL}$ UNSET buffer, $55^{\circ} \mathrm{C} \times 15 \mathrm{~min}^{3}$ \\
\hline \multirow{11}{*}{ Mechanical } & $\mathrm{m}$ & ultrasonic bath sonication & $\mathrm{S} 1$ in ultrasonic cleaner, $40 \mathrm{kHz} \times 15 \mathrm{~min}$ \\
\hline & $\mathrm{n}$ & $\begin{array}{l}\text { glass beads (Bio-Rad, } \\
\text { Hercules, CA, USA)-vortex }\end{array}$ & $\begin{array}{l}0.03 \mathrm{~g} \mathrm{~S} 1+0.3 \mathrm{~g} \text { glass beads }(120-250 \mu \mathrm{m}) \text { in SSW, } \\
\text { vortex in } 1.5 \mathrm{~mL} \text { tube at } 3200 \mathrm{rpm}, 2 \times 20 \mathrm{~min}\end{array}$ \\
\hline & o1 & silica sand-vortex & $\begin{array}{l}0.03 \mathrm{~g} \mathrm{~S} 1+0.3 \mathrm{~g} \text { silica sand }(60-125 \mu \mathrm{m}) \text { in SSW, } \\
\text { vortex in } 1.5 \mathrm{~mL} \text { tube at } 3200 \mathrm{rpm} \text { for } 2 \times 1 \mathrm{~h}\end{array}$ \\
\hline & $\mathrm{o} 2$ & silica sand-vortex & same as group o1 except for size of silica sand $(125-250 \mu \mathrm{m})$ \\
\hline & o3 & silica sand-vortex & same as group o2 except for $2 \times 30 \mathrm{~min}$ \\
\hline & o4 & silica sand-vortex & same as group o2 except for $2 \times 15 \mathrm{~min}$ \\
\hline & o5 & silica sand-vortex & same as group o4 except for using frozen S1 \\
\hline & $\mathrm{p}$ & silica sand-vortex & same as group o4 except for using frozen S3 \\
\hline & $\mathrm{q}$ & silica sand-vortex & same as group o4 except for using S2 \\
\hline & $\mathrm{r}$ & silica sand-vortex & same as group o4 except for using $U$. compressa \\
\hline & $\mathrm{s}$ & silica sand-vortex & same as group o4 except for using $U$. linza \\
\hline
\end{tabular}

${ }^{1}$ SSW, sterile seawater. ${ }^{2}$ [19]. ${ }^{3}$ [20].

\subsection{Denaturing Gradient Gel Electrophoresis}

Based on the results of SEM, some groups were chosen for further denaturing gradient gel electrophoresis (DGGE) analysis. The sterilized thalli in each selected group containing DNA from all endophytes and any potentially remained epiphytes were grounded in liquid nitrogen prior to a total DNA extraction following a CTAB protocol [34]. In addition, the DNA templates for epiphytes solely was extracted from the seawater remained after the sterilization process [19]. PCR was conducted employing the universal bacterial primers F338 (5'-CCTACGGGAGGCAGCAG-3') and R518 (5'-ATTACCGCGGCTGCTGG-3') to amplify the V3 region of 16S rRNA gene [35]. A GC-clamp was coupled to the forward primer to improve DGGE separation. Amplifications were performed in volumes of $50 \mu \mathrm{L}$ containing $10 \times$ PCR buffer $5 \mu \mathrm{L}$, dNTP $(2.5 \mathrm{mM}) 3.2 \mu \mathrm{L}$, rTaq 2 units, GC-338F $(20 \mu \mathrm{M})$ $1 \mu \mathrm{L}, 518 \mathrm{R}(20 \mu \mathrm{M}) 1 \mu \mathrm{L}$, template DNA $50 \mathrm{ng}$. After an initial denaturing step at $94{ }^{\circ} \mathrm{C}$ for $5 \mathrm{~min}, 30$ cycles of denaturing $\left(94{ }^{\circ} \mathrm{C}, 1 \mathrm{~min}\right)$, annealing $\left(55^{\circ} \mathrm{C}, 45 \mathrm{~s}\right)$ and extension $\left(72{ }^{\circ} \mathrm{C}, 1 \mathrm{~min}\right.$ ) were completed, followed by a final amplification step at $72{ }^{\circ} \mathrm{C}$ for $10 \mathrm{~min}$. Successful amplification of the V3 region was verified by the agarose gel electrophoresis. DGGE analysis was conducted using the DCode Universal Mutation Detection System device (Bio-Rad, Hercules, CA, USA). Optimal electrophoretic separation was obtained using $35-55 \%$ denaturing gradient polyacrylamide gels, running for $300 \mathrm{~min}$ at $150 \mathrm{~V}$ in $1 \times$ TAE buffer at a constant temperature of $60^{\circ} \mathrm{C}$. After silver staining, the gels were visualized and digitally captured via the Gel-Doc2000 (Bio-Rad, Hercules, CA, USA). Each selected sample was detected by DGGE in duplicate. The variation of bacterial abundance and diversities among groups were examined based on the DGGE profile. 


\section{Results and Discussions}

The SEM observation showed that attempts to eliminate the epiphytes from Ulva spp. by means of lysozyme, papain, snailase, cellulase, lysozyme + papain + snailase, rapid multienzyme cleaner, ethanol, ultrasonic bath sonication, or glass beads-vortex were all unsuccessful (Figure $1 \mathrm{c}-\mathrm{h}, \mathrm{j}, \mathrm{m}, \mathrm{n}$ ). All of these methods were successful in reducing epiphytes to some extent, but a significant fraction remained evident under SEM detection. These results were consistent with those of DGGE by which the observed patterns in these groups were quite similar to the control (lane m, a; Figure 2), indicating the presence of bulk of epiphytes. In general, various enzymatic sterilization protocols were designed to either directly break up the bacterial cell wall, or to degrade the extracellular polymeric substance (EPS) consisting of polysaccharides, carbohydrate, and proteins produced by bacteria [36]. It was suggested that EPS usually formed a network by which the epiphytes may be tightly associated with the host cells [37], making them difficult to be removed completely from the macroalgae [38]. This may explain the failure in most groups using limited mechanical forces or a single type of enzyme.

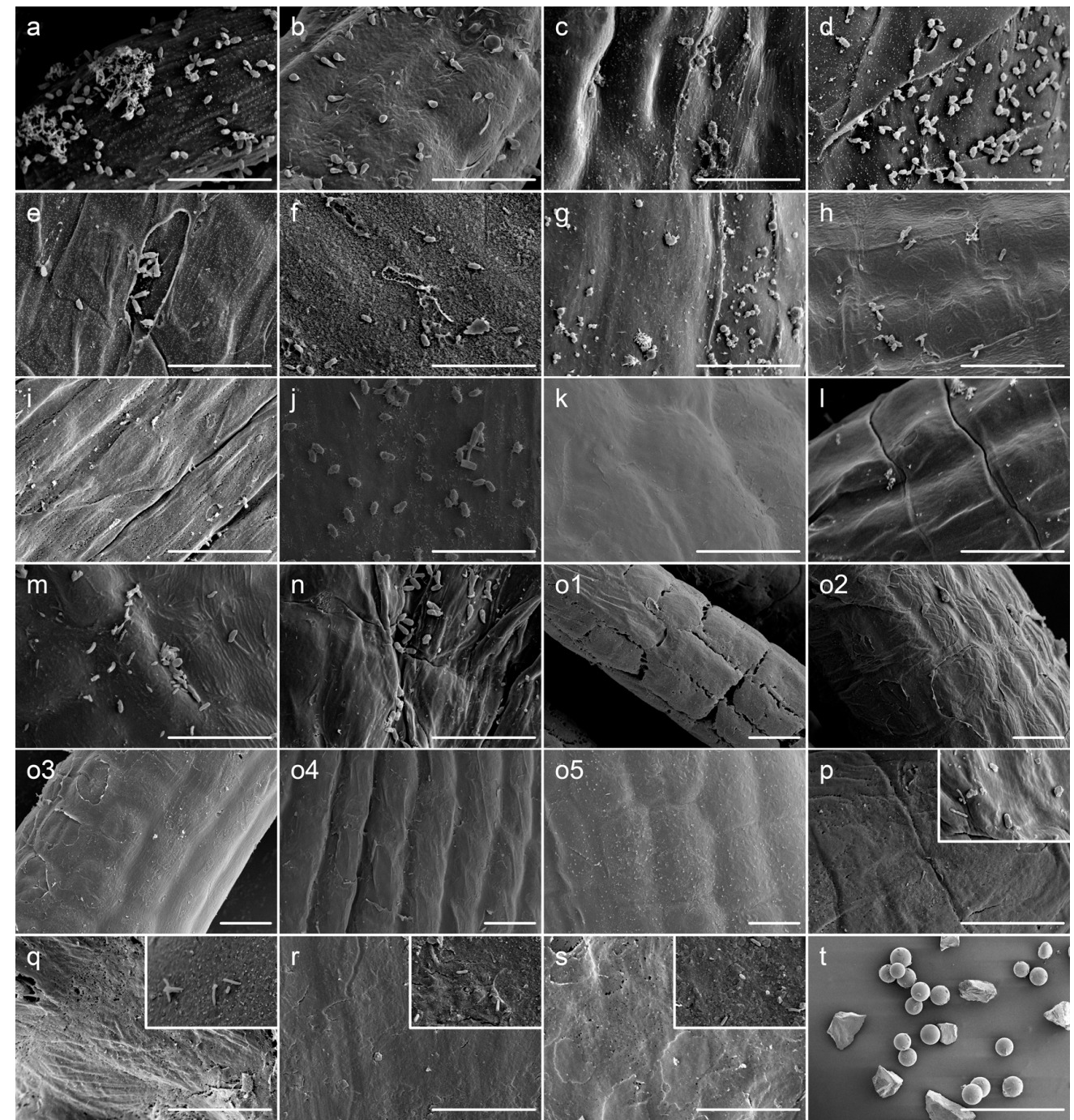

Figure 1. SEM detection for effects of removal of epiphytes by various methods. The characters in each photograph indicate the group described in Table 1 except for group $t$ which was a mixture of glass beads and silica sand. For group (p-s), the control without sterilization was embedded at the top-right corner using the same scale bar. Scale bars $=10 \mu \mathrm{m}$ (group (a-s)), or $1 \mathrm{~mm}$ (group (t)). 




Figure 2. DGGE profiles of $16 \mathrm{~S}$ rDNA V3 fragments amplified from selected groups. The characters on top of each lane indicated the groups described in Table 1 except for group $u$, in which the DNA template representing epiphytes was extracted from the remaining seawater left by group o4. Red arrows indicated partial specific bands from potential endo-bacteria which were absent in group u. Black arrows indicated partial specific bands from potential epi-bacteria which were absent in group 04 .

For proteinase K or UNSET buffer treatment group, it was difficult to detect bacteriashaped particles under the SEM (Figure 1i,l), implying that high-temperature treatment may contribute greatly to the degradation of EPS and elimination of epiphytes. However, some variations on the abundance of putative endosymbionts were revealed by the results of DGGE (lane i, 1; Figure 2). Consequently, if these methods were applied to extract the DNA templates for transcriptome analysis with whole Ulva endosymbionts, the risk of distortion resulted from high-temperature treatment could not be ignored. Moreover, due to the obvious seasonal alternation of epiphytic bacterial structures on Ulva [15], the corresponding potential variations on the EPS components also might limit the utilization of enzymatic or chemical methods.

Of all of the chemical biocides for biofilm control, chlorine was the most commonly used strong oxidizing agent and disinfectant [39]. Sodium hypochlorite has been shown to be effective for surface sterilization against red, green or brown seaweeds [23], and has been used for endosymbiont composition analysis for green alga Caulerpa which has highly differentiated morphology [22]. In this study, the bleach method using sodium hypochlorite can get rid of all epiphytes in seconds (Figure 1k), but it was too aggressive for U. prolifera that took the form of monostromatic thallus without a protective surface, causing the endosymbionts to almost completely disappear (lane k; Figure 2). This phenomenon has also been observed in another delicate green alga Bryopsis [21].

In contrast to all of the other methods tested, the results showed that a newly developed mechanical method (i.e., co-vortex of Ulva thalli with sterilized silica sands at room temperature) was the best method to balance the maximized removal of epiphytes and minimized interference to the endophytes. The results of SEM showed that the cleaned seaweeds with almost complete removal of epiphytes could be obtained by our method using silica sands of 60-125 $\mu \mathrm{m}$ or 125-250 $\mu \mathrm{m}$ diameter. Since silica sands with smaller size were found to have obvious damage to Ulva cell walls (Figure 1(o1)), the optimized parameters (i.e., vortex at $3200 \mathrm{rpm}$ for $2 \times 15 \mathrm{~min}$ with silica sands in size of 125-250 $\mu \mathrm{m}$ ) were determined by comparisons. It was indicated that this protocol could keep almost no epiphytes remained on the surface of Ulva thalli even for frozen samples (Figure 1(o4,o5)), and the adaptability was verified among other $U$. prolifera strains (Figure 1p,q), as well as 
other Ulva species that were in the shape of either blade-like or tubular thalli (Figure 1r,s). Compared to glass beads in a similar size (Figure 1t), more irregular shapes of sand particles may contribute to the success of this new method by generating greater friction force. More importantly, when comparing the lane o4 and lane $u$ from DGGE gel in Figure 2, some specific bands could be identified in each lane, implying the existence of specific endo- or epi-bacteria. It was believed that the bands shared in these two lanes might come from a very small number of epiphytes remains after vortex, but they were more likely to come from those non-specific strains in terms of spatial localization, which were distributed both on the surface and inside the algal thalli, as happened in the drifting Sargassum horneri [18]. In addition, the results of DGGE also clearly showed that the silica-sands group (lane o4; Figure 2) got much richer signals than the bleach group (lane k; Figure 2), indicating that vortex treatment had the least potential interference with endosymbionts, which would be beneficial for the $16 \mathrm{~S}$ rRNA metabarcoding or transcriptome analysis of this special bacterial group.

It has to be pointed out that the specific parameter of this developed protocol was only suitable for algae with simple shapes such as Ulva. For algal species with complex structures, there was no doubt that a certain number of epiphytes were likely to remain after treatments. Therefore, further parameters optimization or careful selection of algal segments would be necessary. In these situations, even if complete removal of epiphytic bacteria could not be achieved, the significant reduction in the abundance of epiphytes was still helpful since it might allow the low abundant endophytic bacterial populations to be detected. Meanwhile, the co-vortex with glass beads has been used to remove the epiphytes in red macroalga Gracilaria [40], which indicates that this kind of mechanical method (i.e., co-vortex with particles) is generally applicable across species in seaweeds and can be preferentially employed to analyze the community structure of epiphytes using $16 \mathrm{~S}$ rRNA metabarcoding.

\section{Conclusions}

In summary, an efficient, rapid, and easy mechanical method to almost completely remove the epiphytic bacteria from fresh or frozen Ulva, and to keep the fidelity of endophytes to the greatest extent, was developed. This method was capable of analyzing the community composition and host specificity between these two types of bacterial groups simultaneously or providing epiphytes-free living algae thalli (especially for those species with simple shapes).

Author Contributions: Conceptualization, P.J. and X.L.; methodology, P.J. and X.L.; validation, X.L.; formal analysis, X.L. and P.J.; resources, J.Z.; data curation, X.L.; writing-original draft preparation, X.L.; writing—review and editing, P.J.; supervision, P.J.; project administration, P.J.; funding acquisition, P.J. All authors have read and agreed to the published version of the manuscript.

Funding: This research was supported by National Key R\&D Program of China (2018YFD0901500), National Natural Science Foundation of China (41776153), Key Deployment Project of Centre for Ocean Mega-Research of Science, Chinese Academy of Science (COMS2019Q05), Key R\&D Program of Shandong Province (2019GSF107012), and Strategic Priority Research Program of the Chinese Academy of Sciences (XDA23050302, XDB42030302).

Institutional Review Board Statement: Not applicable.

Informed Consent Statement: Not applicable.

Data Availability Statement: Not applicable.

Conflicts of Interest: The authors declare no conflict of interest. 


\section{References}

1. Goecke, F.; Labes, A.; Wiese, J.; Imhoff, J.F. Chemical interactions between marine macroalgae and bacteria. Mar. Ecol. Prog. Ser. 2010, 409, 267-299. [CrossRef]

2. Croft, M.T.; Lawrence, A.D.; Raux-Deery, E.; Warren, M.J.; Smith, A.G. Algae acquire vitamin B-12 through a symbiotic relationship with bacteria. Nature 2005, 438, 90-93. [CrossRef] [PubMed]

3. Berg, G.M.; Repeta, D.J.; Laroche, J. Dissolved organic nitrogen hydrolysis rates in axenic cultures of Aureococcus anophagefferens (Pelagophyceae): Comparison with heterotrophic bacteria. Appl. Environ. Microbiol. 2002, 68, 401-404. [CrossRef] [PubMed]

4. Dobretsov, S.V.; Qian, P.Y. Effect of bacteria associated with the green alga Ulva reticulata on marine micro- and macrofouling. Biofouling 2002, 18, 217-228. [CrossRef]

5. Ghaderiardakani, F.; Quartino, M.L.; Wichard, T. Microbiome-dependent adaptation of seaweeds under environmental stresses: A perspective. Front. Mar. Sci. 2020, 7, 575228. [CrossRef]

6. Patel, P.; Callow, M.E.; Joint, I.; Callow, J.A. Specificity in the settlement-modifying response of bacterial biofilms towards zoospores of the marine alga Enteromorpha. Environ. Microbiol. 2003, 5, 338-349. [CrossRef]

7. Matsuo, Y.; Imagawa, H.; Nishizawa, M.; Shizuri, Y. Isolation of an algal morphogenesis inducer from a marine bacterium. Science 2005, 307, 1598. [CrossRef]

8. Marshall, K.; Joint, I.; Callow, M.E.; Callow, J.A. Effect of marine bacterial isolates on the growth and morphology of axenic plantlets of the green alga Ulva linza. Microbial. Ecol. 2006, 52, 302-310. [CrossRef]

9. Spoerner, M.; Wichard, T.; Bachhuber, T.; Stratmann, J.; Oertel, W. Growth and thallus morphogenesis of Ulva mutabilis (Chlorophyta) depends on a combination of two bacterial species excreting regulatory factors. J. Phycol. 2012, 48, 1433-1447. [CrossRef]

10. Wichard, T. Exploring bacteria-induced growth and morphogenesis in the green macroalga order Ulvales (Chlorophyta). Front. Plant Sci. 2015, 6, 86. [CrossRef]

11. Wichard, T.; Charrier, B.; Mineur, F.; Bothwell, J.H.; De Clerck, O.; Coates, J.C. The green seaweed Ulva: A model system to study morphogenesis. Front. Plant Sci. 2015, 6, 72. [CrossRef] [PubMed]

12. Alsufyani, T.; Califano, G.; Deicke, M.; Grueneberg, J.; Weiss, A.; Engelen, A.H.; Kwantes, M.; Mohr, J.F.; Ulrich, J.F.; Wichard, T. Macroalgal-bacterial interactions: Identification and role of thallusin in morphogenesis of the seaweed Ulva (Chlorophyta). J. Exp. Bot. 2020, 71, 3340-3349. [CrossRef] [PubMed]

13. Egan, S.; Thomas, T.; Holmstrom, C.; Kjelleberg, S. Phylogenetic relationship and antifouling activity of bacterial epiphytes from the marine alga Ulva lactuca. Environ. Microbiol. 2000, 2, 343-347. [CrossRef] [PubMed]

14. Delbridge, L.; Coulburn, J.; Fagerberg, W.; Tisa, L.S. Community profiles of bacterial endosymbionts in four species of Caulerpa. Symbiosis 2004, 37, 335-344.

15. Burke, C.; Thomas, T.; Lewis, M.; Steinberg, P.; Kjelleberg, S. Composition, uniqueness and variability of the epiphytic bacterial community of the green alga Ulva australis. ISME J. 2011, 5, 590-600. [CrossRef]

16. Aires, T.; Serrao, E.A.; Kendrick, G.; Duarte, C.M.; Arnaud-Haond, S. Invasion is a community affair: Clandestine followers in the bacterial community associated to green algae, Caulerpa racemosa, track the invasion source. PLoS ONE 2013, 8, e68429. [CrossRef]

17. Fu, H.H.; Jiang, P.; Zhao, J.; Wu, C.H. Comparative genomics of Pseudomonas sp. strain SI-3 associated with macroalga Ulva prolifera, the causative species for green tide in the Yellow Sea. Front. Microbiol. 2018, 9, 1458. [CrossRef]

18. Mei, X.Y.; Wu, C.H.; Zhao, J.; Yan, T.; Jiang, P. Community structure of bacteria associated with drifting Sargassum horneri, the causative species of golden tide in the Yellow Sea. Front. Microbiol. 2019, 10, 1192. [CrossRef]

19. Burke, C.; Kjelleberg, S.; Thomas, T. Selective extraction of bacterial DNA from the surfaces of macroalgae. Appl. Environ. Microbiol. 2009, 75, 252-256. [CrossRef]

20. Fisher, M.M.; Wilcox, L.W.; Gram, L.E. Molecular characterization of epiphytic bacterial communities on Charophycean green algae. Appl. Environ. Microbiol. 1998, 64, 4384-4389. [CrossRef]

21. Hollants, J.; Leliaert, F.; De Clerck, O.; Willems, A. How endo- is endo-? Surface sterilization of delicate samples: A Bryopsis (Bryopsidales, Chlorophyta) case study. Symbiosis 2010, 51, 131-138. [CrossRef]

22. Aires, T.; Marba, N.; Serrao, E.A.; Duarte, C.M.; Arnaud-Haond, S. Selective elimination of chloroplastidial DNA for metagenomics of bacteria associated with the green alga Caulerpa taxifolia (Bryopsidophyceae). J. Phycol. 2012, 48, 483-490. [CrossRef] [PubMed]

23. Kientz, B.; Thabard, M.; Cragg, S.M.; Pope, J.; Hellio, C. A new method for removing microflora from macroalgal surfaces: An important step for natural product discovery. Bot. Mar. 2011, 54, 457-469. [CrossRef]

24. Wang, H.X.; Geng, Z.L.; Zeng, Y.; Shen, Y.M. Enriching plant microbiota for a metagenomic library construction. Environ. Microbiol. 2008, 10, 2684-2691. [CrossRef] [PubMed]

25. Fletcher, R.L. The occurrence of "green tides"-A review. In Marine Benthic Vegetation: Recent Changes and the Effects of Eutrophication; Schramm, W., Nienhuis, P.H., Eds.; Springer: Berlin/Heidelberg, Germany, 1996; pp. 7-43.

26. Smetacek, V.; Zingone, A. Green and golden seaweed tides on the rise. Nature 2013, 504, 84-88. [CrossRef]

27. Blomster, J.; Bäck, S.; Fewer, D.P.; Kiirikki, M.; Lehvo, A.; Maggs, C.A.; Stanhope, M. Novel morphology in Enteromorpha (Ulvophyceae) forming green tides. Am. J. Bot. 2002, 89, 1756-1763. [CrossRef] [PubMed]

28. Zhang, J.H.; Huo, Y.Z.; Zhang, Z.L.; Yu, K.F.; He, Q.; Zhang, L.H.; Yang, L.L.; Xu, R.; He, P.M. Variations of morphology and photosynthetic performances of Ulva prolifera during the whole green tide blooming process in the Yellow Sea. Mar. Environ. Res. 2013, 92, 35-42. [CrossRef] 
29. Gao, G.; Zhong, Z.; Zhou, X.; Xu, J. Changes in morphological plasticity of Ulva prolifera under different environmental conditions: A laboratory experiment. Harmful Algae 2016, 59, 51-58. [CrossRef]

30. Qu, T.; Hou, C.; Zhao, X.; Zhong, Y.; Guan, C.; Lin, Z.; Tang, X.; Wang, Y. Bacteria associated with Ulva prolifera: A vital role in green tide formation and migration. Harmful Algae 2021, 108, 102104. [CrossRef]

31. Zhao, J.; Jiang, P.; Liu, Z.Y.; Wei, W.; Lin, H.Z.; Li, F.C.; Wang, J.F.; Qin, S. The Yellow Sea green tides were dominated by one species, Ulva (Enteromorpha) prolifera, from 2007 to 2011. Chin. Sci. Bull. 2013, 58, 2298-2302. [CrossRef]

32. Zhao, J.; Jiang, P.; Qin, S.; Liu, X.J.; Liu, Z.Y.; Lin, H.Z.; Li, F.C.; Chen, H.X.; Wu, C.H. Genetic analyses of floating Ulva prolifera in the Yellow Sea suggest a unique ecotype. Estuar. Coast. Shelf Sci. 2015, 163, 96-102. [CrossRef]

33. Callow, M.E.; Evans, L.V.; Bolwell, G.P.; Callow, J.A. Fertilization in brown-algae. 1. SEM and other observations on Fucus serratus. J. Cell Sci. 1978, 32, 45-54. [CrossRef] [PubMed]

34. Doyle, J.J.; Doyle, J.L. Isolation of plant DNA from fresh tissue. Focus 1990, 12, 13-15.

35. Muyzer, G.; Dewaal, E.C.; Uitterlinden, A.G. Profiling of complex microbial-populations by denaturing gradient gelelectrophoresis analysis of polymerase chain reaction-amplified genes-coding for 16S ribosomal-RNA. Appl. Environ. Microbiol. 1993, 59, 695-700. [CrossRef] [PubMed]

36. Lawrence, J.R.; Swerhone, G.D.W.; Leppard, G.G.; Araki, T.; Zhang, X.; West, M.M.; Hitchcock, A.P. Scanning transmission X-ray, laser scanning, and transmission electron microscopy mapping of the exopolymeric matrix of microbial biofilms. Appl. Environ. Microbiol. 2003, 69, 5543-5554. [CrossRef]

37. Singh, R.P.; Reddy, C.R.K. Seaweed-microbial interactions: Key functions of seaweed-associated bacteria. FEMS Microbiol. Ecol. 2014, 88, 213-230. [CrossRef]

38. Barreto, M.; Meyer, J.J.M. The preservation of biofilms on macroalgae by osmium vapour. S. Afr. J. Bot. 2007, 73, 64-69. [CrossRef]

39. de Beer, D.; Srinivasan, R.; Stewart, P.S. Direct measurement of chlorine penetration into biofilms during disinfection. Appl. Environ. Microbiol. 1994, 60, 4339-4344. [CrossRef]

40. Saha, M.; Wiese, J.; Weinberger, F.; Wahl, M. Rapid adaptation to controlling new microbial epibionts in the invaded range promotes invasiveness of an exotic seaweed. J. Ecol. 2016, 104, 969-978. [CrossRef] 